УдК 616-022.8:581.49

\title{
COMPARATIVE CHARACTERISTICS OF POLLEN FALL OF ALERGENIC PLANTS IN WIELKAPOLSKA REGION (POLAND) AND IN LVIV CITY (UKRAINE)
}

\author{
N.Kalinovych ${ }^{1}$, A.Stach ${ }^{2}$, M.Chernetsky ${ }^{3}$, \\ A.Uruska ${ }^{4}$, M.Nowak ${ }^{2}$, A.Szymanska \\ ${ }^{1}$ Ivan Franko National University of Lviv. Division of Botany \\ 4, Hrushevskyi St., 79005 Lviv, Ukraine \\ e-mail: natluchnnn@netscape.net \\ ${ }^{2}$ Adam Mickiewicz University. Laboratory of Aeropalynology \\ 89, Umultowska St., 61-614 Poznan, Poland \\ e-mail: ambrozja@man.poznan.pl \\ ${ }^{3}$ Agricultural University in Lublin. Department of Botany \\ 15, Akademicka St., 20-950 Lublin, Poland \\ e-mail: mczerneckyj@yahoo.com \\ ${ }^{4}$ Gdansk University. Laboratory of Palaeoecology and Archaeobotany \\ 9, Legionow St., 80-441 Gdansk, Poland \\ e-mail: bioaj@univ.gda.pl
}

Airborne ragweed (Ambrosia) and pigweed (Chenopodiaceae) pollen concentration in central part of Poland (Warta Landscape Park) and western part of Ukraine (Lviv city) was studied. In both regions, higher concentration of Ambrosia pollen comparing to Chenopodiaceae pollen was recorded, despite of pigweed population was significantly more abundant on the territory of Poland and western Ukraine. In peaks of pollination, the Ambrosia pollen concentration reached high level of 50-60 pollen grains per cubic metre of air (p.g. $/ \mathrm{m}^{3}$ ) and Chenopodiaceae pollen concentration amounted 25 p.g. $/ \mathrm{m}^{3}$ in Lviv and 15 p.g. $/ \mathrm{m}^{3}$ in Wielkapolska region. Three peaks of Ambrosia pollination were observed in Ukraine and in Poland with several days delay in Poland. Because of absence of Ambrosia population in neighborhood of Poznan, it was suggested that a long distance transportation from the territory of Ukraine took place. Aeropalynological monitoring in the eastern regions of Europe can provide preventive information about critical periods of allergenic plants pollination.

Key words: aerobiology, palynology, pollen fall, Ambrosia, Chenopodiaceae. 


\title{
ПОРІВНЯЛЬНА ХАРАКТЕРИСТИКА ПИЛКОВОГО ОПАДУ АЛЕРГЕННИХ РОСЛИН У ВЕЛИКОПОЛЬСЬКОМУ РЕГІОНІ (ПОЛЬЩА) І ЛЬВОВІ (УКРАÏНА)
}

\author{
Н.Калинович1, А.Стах ${ }^{2}$, М.Чернецький ${ }^{3}$, \\ А.Уруска4, М.Новак ${ }^{2}$, А.Шиманська \\ ${ }^{1}$ Львівський національний університет імені Івана Франка. Кафедра ботаніки \\ вул.Грушевського, 4, Львів 79005, Україна \\ e-mail: natluchnnn@netscape.net \\ 2університет імені Адама Міцкевича. Лабораторія аеропалінології \\ вул.Умултовська, 89, Познань 61-614, Польща \\ e-mail: ambrozja@man.poznan.pl \\ ЗЛюблінський аграрний університет. Кафедра ботаніки \\ вул.Академічна, 15, Люблін 20-950, Польща \\ e-mail: mczerneckyj@yahoo.com \\ 4Гданський університет. Лабораторія палеоекології і археоботаніки \\ вул.Легіонів, 9, Гданськ 80-441, Польща \\ e-mail: bioaj@univ.gda.pl
}

Досліджено концентрацію пилку амброзії (Ambrosia) і лободових (Chenopodiaceae) в атмосфері центральної Польщі та західної України. У повітрі обох регіонів виявлено значно більшу концентрацію пилку Ambrosia, ніж Chenopodiaceae, попри ряснішу заселеність досліджуваних територій лободовими. Під час піків пилення концентація пилку Ambrosia сягала високого рівня: 50-60 пилкових зерен у кубічному метрі повітря (п.з. $/ \mathrm{M}^{3}$ ), а Chenopodiaceae - низького: 25 п.з./ $\mathrm{M}^{3}$ у Львові та 15 п.з./ $\mathrm{M}^{3}$ у Великопольському регіоні. В Україні й Польщі виявлено по три піки пилення амброзії із запізненням у декілька днів на території Польщі. Зважаючи на відсутність місцезростань амброзії в околицях Познаня зроблено висновок про перенесення її пилку з території України. Отже, аеропалінологічний моніторинг у східних регіонах Європи може забезпечити алергетиків і алергологів попереджувальною інформацією про критичні періоди пилення алергенних рослин.

Ключові слова: аеробіологія, палінологія, пилковий опад, Ambrosia, Chenopodiaceae.

\section{INTRODUCTION}

Aerobiology is a scientific discipline focused on the study of airborne organisms and biological materials that are transported passively in the air. The viable biological particles include microorganisms (viruses, bacteria, fungi and their spores), algal cells, lichen propagules, protozoan cysts, and spores of bryophytes, lycopodiophytes, equisetophytes, pteridophytes, and pollen grains. Aerobiology deals with their dispersion and transportation, deposition or other ways of removal from the air and their impact on animal, plant and human systems. Aerobiology is an interdisciplinary science connecting many different subjects including Botany, Ecology, Meteorology, Agriculture and Allergology [14].

Aerobiology has many applications, including crop pathology, conservation of cultural heritage, and forensic investigation [39, 42, 43, 45, 46]. Medicine is the most important application of Aerobiology. First of all, it is concerned with the transmission of airborne diseases. It is known that many bacteria and viruses can be transmitted 
through air, possibly within droplets. Besides, aerobiological research is often concerned with pollen and spore allergy.

Allergic diseases are considered to be among the most important contemporary health problems. Extensive epidemiological evidence from all over the world has recently been accumulated indicating that allergic diseases affect up to $25 \%$ of the world population [9]. Pollen allergy is the most typical form of allergic disease.

Pollen grains contain many different types of proteins. Some of them are allergenic. Allergenic proteins are located in various parts of pollen grain:

- exine: in the surface depressions and in the cavities between the baculae;

- intine: mostly concentrated near the germopore;

- cytoplasm: in cytosol, starch granules, endoplasmic reticulum cisterns, Golgi body and mitochondria.

Allergenic proteins of pollen grains have molecular mass similar to that of most enzymes, $10-70 \mathrm{kDa}$. Some of these aeroallergens are proteolytic enzymes. They are released rapidly in several minutes from pollen grains after moistening. In days following a rainfall, fifty fold increase of these starch granules was noticed in the atmosphere [68].

Symptoms of sensitivity to allergens in pollen typically develop upon the contact of pollen with the mucosal surfaces of eyes, nose and throat of sensitized individuals [4]. Typically, this results in development of conjunctivitis, nasal congestion, sneezing and irritation of eyes, nose and throat. Hay fever is often a result of inhalation of whole pollen or large pollen particles. Smaller pollen particles and allergen-carrying components can often be inhaled into the lower airways where they induce a development of asthmatic symptoms in sensitive individuals, including breathlessness, mucosal inflammation and hyper secretion, muscle hyper-reactivity and anxiety [67].

In numerous studies have been conducted to identify allergenic pollen species. The specimens of the following plant groups are considered to be allergenic plants in Europe: Alnus, Corylus, Betula, Poaceae, Asteraceae, Artemisia, Ambrosia, Cupressaceae, Taxus, Fagus, Quercus, Fraxinus, Olea, Salix, Urtica/Parietaria, Platanus, Aesculus, Castanea, Chenopodiaceae/Amaranthaceae, Rumex, Plantago, Ulmus, Juglans, Sambucus, and others [11].

Several studies showed a strong association between the increase in pollen in the atmosphere and the increase in allergic diseases in relation to the sensitization $[2,25$, 53]. Much attention has been paid to finding a correlation between the concentration of airborne pollen and incidences of allergy, estimating the lowest average concentrations for various species of airborne pollen that elicit allergic symptoms when exceeded [5, $32,44,51,52]$. An important question in this field of research is how to prevent a man from developing pollen allergy. One way of prevention is, naturally, to avoid exposure to allergenic pollen as much as possible. A close cooperation between clinicians and aerobiologists in terms of pollination monitoring is necessary. Forecasting pollination helps allergists to establish an appropriate prevention for allergic patients. Pollen allergies are often termed „seasonal”. Thus, patients need calendars that show a distribution of allergenic pollen throughout the year.

During the last decades of the XX century, a lot of pollen calendars for different European countries were published $[6,12,18,22,31,35,36,47,56,60,66]$. These calendars are based on a long-term pollen monitoring. Following parameters are frequently present in the calendars for each allergenic group of plants: start and end of pollination, pollination season duration, main pollen period with the diurnal fluctuation, peaks of the pollen season, and days with pollen concentration higher than a certain level according to such categories as low, moderate, high, and very high. Pollen calendars are sometimes not only constructed according to country boundary, but also according to criteria of natural environment, such as geography and climate [57]. 
Most forecasting systems are adapted to a certain region. General forecasting model that might fit all European regions is not yet available, though some attempts have been done to create it $[8,16,59]$.

The environmental factors play an important role in solving the problem of pollen allergy. Much attention has been paid to determining pollen allergenicity in polluted and non-polluted environmental conditions. According to experimental data, the polluted pollen is more effective than non-polluted one. Scanning electron microscope studies of pollen grains show that in polluted areas, airborne particles were accumulated on the surface of pollen grains and changed both pollen's shape and tectum. Many vesicles were also released from polluted pollen and the pollen material agglomerated on the surface of pollen [40].

Climatic conditions are capable of modifying a number of pollen grains in the atmosphere, and, consequently, in modifying an incidence of allergic symptoms [15]. Previous studies have related meteorological variables to airborne pollen counts; patients suffer allergy episodes before the peak of pollen appearance is reached. For this reason joining together a long-term climatic data, number of years of pollen data collection, mathematical models and phenological botanical studies more accurate results can be achieved [5, 53].

A phenomena that might be reflected in pollen concentrations data is an evidence of global climate. The flowering times of many plants have altered and higher annual average temperatures have led to increase of pollen concentration of some taxa in the atmosphere [7, 16, 21, 38, 59]. These trends emphasize the need for continued long-term monitoring over a wide network of sites.

More than sixty percent of the world's population live in the cities with more than 10,000 inhabitants. It is therefore very important to understand the climate of urban areas and the ways in which they influence a dispersal of biological particles. The air in cities is usually warmer than that in a surrounding country-side, partly because of heat from buildings which includes lighting and power plant and partly due to a difference in albedo. This warmer air over the city is known as the urban heat island effect. This is important for aerobiology in several ways. It influences the phenology of plants within the city, often giving an earlier start to the growing season compared with the surrounding rural areas. The heat island also affects airflow patterns and local stability.

Aerobiology develops in close international collaboration. In 1968, the International Aerobiology Working Group was constituted to coordinate all national aerobiological programs. In 1974, the International Association for Aerobiology (IAA) was founded. The IAA organises the Quadrennial Congress (International Congress on Aerobiology). Twice a year the IAA publishes the International Aerobiology Newsletter. There are two main European journals which publish the papers in aerobiological area: „Aerobiologia" International Journal of Aerobiology and „Grana” - An International Journal of Palynology and Aerobiology.

In different European countries numerous new pollen-monitoring stations were installed. Chief members of IAA took a decision about the skill of new comers. So since 1993 to 2005, seven European Courses in Basic Aerobiology were held. Apart from introductory theoretical lectures on fundamental aspects of aerobiology, most of the time was spent on demonstrating and training the internationally accepted sampling and counting techniques, and on reliable recognition of the commonest pollen taxa and fungal spores in Europe [58]. The main goal of those courses was to work out the unified methodology of aerobiological investigation for creation of general European data base.

In total, information from more than 500 pollen monitoring stations from 49 European countries is involved in the European Pollen Information System (EPI), which consists 
of three coherent units: the European aeroallergen database (EAN), the public web portal of EPI http://www.polleninfo.org/ and a commercial branch „epi Ltd.”. Good cooperation between these three units results in the creation of precise pollination maps for various regions of Europe and effective transfer of information about pollen concentrations [29]. Common methodology should be developed to make possible a comparison of data obtained in different sampling points. The idea is to produce a common protocol to be used by all members belonging to the network. At the European level, the European Aeroallergen Network/European Pollen Information (EAN/EPI) has agreed some rules, such as the use of based Hirst type sampler; to analyse at least $10 \%$ of total sampling; and to express the data in daily average pollen grains per cubic meter of air [19]. The data of EPI are socially useful. It is not enough to produce valuable information but to publish this information in a convenient manner in order to be understood by all social groups. Aerobiological monitoring stations provide weekly information for the media, such as TV, radio, teletext, websites and newspapers [50].

At present, Aerobiology is a rapidly developing science. Aerobiological research engages hundreds of scientists throughout the world. The palynological laboratory, like many other similar institutions, participates in a number of different aerobiological research projects in various areas. Our article was prepared within „AEROTOP” project, supported by the European research program „FP6 - Marie Curie Transfer of Knowledge” and coordinated by Dr Alicja Stach from Laboratory of Aeropalynology of Adam Mickiewicz University (Poznan, Poland). The Plant Biology Department (University of Cordoba, Spain) and National Pollen and Aerobiology Research Unit (University of Worcester, UK) take part in „AEROTOP”. The main goal of Ukrainian researcher participation in this project, is to recognize general methodology of modern aerobiological investigations for prospective organization of such investigation in Lviv (Ukraine). The authors look forward to the opportunity of creating an Aerobiological Centre in Ukraine and its involvement in the European collaboration. There are only some short communications that present aeropalynological data from Ukraine [10, 33, 34, 69]. Unfortunately, all of them were obtained with using gravimetric method. Thus, organization of modern aerobiological investigation techniques in Ukraine is urgently needed.

\section{MATERIAL AND METHODS}

Presented data have been obtained for Warta Landscape Park (Poland) and Lviv city (Ukraine).

Warta Landscape Park situated at the central part of Poland in the neighborhood of Poznan sity. From the climatic point of view, this region experiences a warm and moderate dry lowland climate with an average annual temperature of $8^{\circ} \mathrm{C}$. An average annual precipitation is $528 \mathrm{~mm}$. Predominant winds blow from W and N sectors [70]. Actual vegetation is presented with wet forests with Salix and Alnus in flood land of Warta River and wet meadows. In the border of the valley, some forest areas with Pinus, Quercus, Fraxinus are present. Lands in the near neighborhood were transformed into agricultural areas.

Volumetric methods have been applied for pollen collection with the use of a Burkard trap [24]. The trap was placed on a flat roof of the about $15 \mathrm{~m}$ above ground level. The trap is fitted with a drum, around which a sticky cellulose strip is placed. Clockwork mechanism moves the drum at the rate of $2 \mathrm{~mm}$ per hour past a narrow slit in casing that encloses the drum. By means of a vacuum pump, air is ducked through this slit at a constant rate of 10 liters per minute. This volume of air flows over the trapping surface, depositing pollen grains and fungal spores on the sticky strip [14]. 
The cellulose strip was removed from the drum after seven days and divided into several equal sections, each representing a $24 \mathrm{~h}$ period. These strip sections were prepared for microscopy by placing them on microscopic glass coated with the Gevatol adhesive substance. A basic fuchsine stain has been used to facilitate the identification of pollen grains. Samples were examined under a light microscope at $400 \times$ magnification [61]

Pollen grains for four longitudinal bands have been identified and counted per slide [17]. The number of pollen counted in each sample, has been expressed in daily average pollen grains per cubic meter of air. The trap continuously sucks in 10 liters per minute and therefore $14.4 \mathrm{~m}^{3}$ of air per day. All pollen grains contained in this volume, are deposited over total surface of $672 \mathrm{~mm}^{2}$ of the tape. This area represents the surface of a daily sample $(14 \times 48 \mathrm{~mm})$. Knowing the total examined surface, it was easy to convert, with a simple proportion, the number of pollen recorded under the microscope in the number of pollen present in the entire daily sample. All concentrations used in this study are average daily pollen concentrations per $\mathrm{m}^{3}$ of air.

Pollen data for Lviv city have been obtained using the gravimetric method. As surface for pollen deposition, we used microscopic glass covered with glycerin and exposed to the air for $24 \mathrm{~h}$ periods. The glasses were placed into Duram apparatus which was located at $18 \mathrm{~m}$ above ground level. The pollen collection was curried out in the southwestern part of Lviv city in the district of compact tenement-houses with typical for western Ukraine green plantations consisted of Tilia, Betula, Acer, Fraxinus, Corylus, Picea and others. The glasses were changed daily. The quantitative and qualitative composition of the pollen fall was determined on $14 \times 48 \mathrm{~mm}$ surface of the microscopic glass.

The deposition glasses indicate of the types and quantities of pollen present in the air, but do not show its concentrations. So we used special factor for calculation to make the data obtained with gravimetric method comparable to those obtained with volumetric method [3].

\section{RESULTS}

In our study, we addressed the problem of pollen fall of two allergenic groups of plants ragweed (Ambrosia) and pigweed (Chenopodiaceae).

Ambrosia is a highly allergenic, anemophilous genus of the Asteraceae family composed of 35-40 species. A few species among them are recognized in Europe [23]. Great part of the territory of Ukraine is populated with three species of this genus Ambrosia artemisiifolia L., A. trifida L., and A. aptera DC. Ragweed grows on the uncultivated ground, along roads, railways and watercourses, as well as among cultivated plants, preferably in a warm climate and dry soil in the eastern, southern and central regions of Ukraine. Only few small localities are recognized in Lviv city. Ambrosia-type pollen includes the pollen of Xanthium and Cyclachaena (Iva) genera that are not abundant, although they passess allergenic character that similar to Artemisia.

In Poland, Ambrosia occurs in small scattered stands. An occurrence of Ambrosia artemisiifolia L., A. psilostachya DC., and A. arenaria (L.) Link has been noted in Poland but only $A$. artemisiifolia occurs more commonly [71]. No stands of Ambrosia are known in Poznan and its vicinity.

Ragweed is an anemophilous one and a plant produces several millions of pollen grains travelling long distances because of their small size. Recently, we have noticed a progressive diffusion of the exotic Ambrosia in many European countries.

Chenopodiaceae-type pollen includes the pollen of Amaranthaceae family too. Chenopodiaceae family representatives are widely spread in Polland and Ukraine. Among them there are well known cultivated species such as spinach and beet. The wild species of Chenopodiaceae family are plants that prosper in desolate areas and land left fallow, 
especially in irrigated land. Representatives of Amaranthaceae family are mainly weeds and some of them are introduced from tropical areas as ornamental plants.

Because of allergenic character, monitoring of ragweed and pigweed pollen has been performed in Europe for years. The aim of our study is to compare the seasonal daily and intradiurnal fluctuations of Ambrosia and Chenopodiaceae pollen concentrations in atmosphere of two different regions of Central Europe.

The obtained data are presented in the Figures 1-4. All pollen concentrations are expressed as number of pollen grains per cubic meter of air.

The results of the present study showed a broad similarity in behaviour and duration of Ambrosia pollen season in investigated regions of Poland and Ukraine. Ragweed pollen is present in the air of Lviv and Poznan vicinity from the beginning of August till the end of September, with three remarkable peaks of pollination between mid-August and mid-September (Fig. 1). The start of the pollen season was defined as the moment at which pollen appears in air continuously. Generally, amounts of Ambrosia pollen were quite low and did not exceed $10 \mathrm{p.g} . / \mathrm{m}^{3}$. In maximum of pollination, the pollen account reached 50 p.g. $/ \mathrm{m}^{3}$ in the Ukrainian location and 60 p.g. $/ \mathrm{m}^{3}$ in the

WARTA LANDSCAPE PARK, 2005

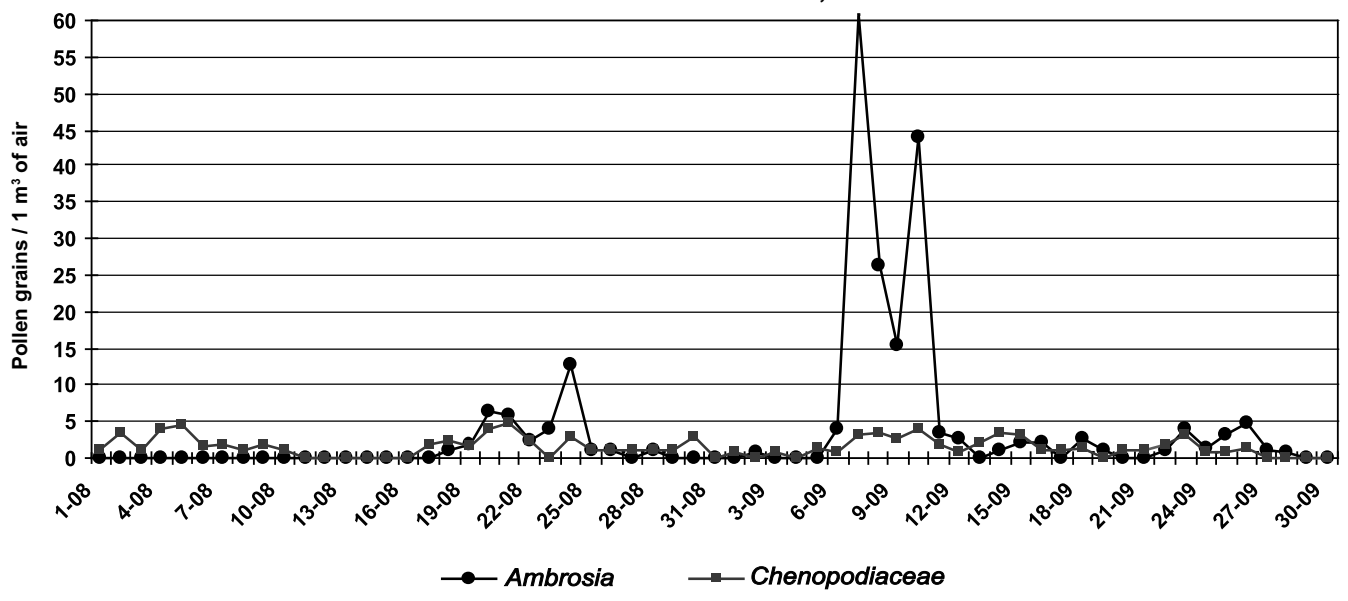

LVIV, 2002

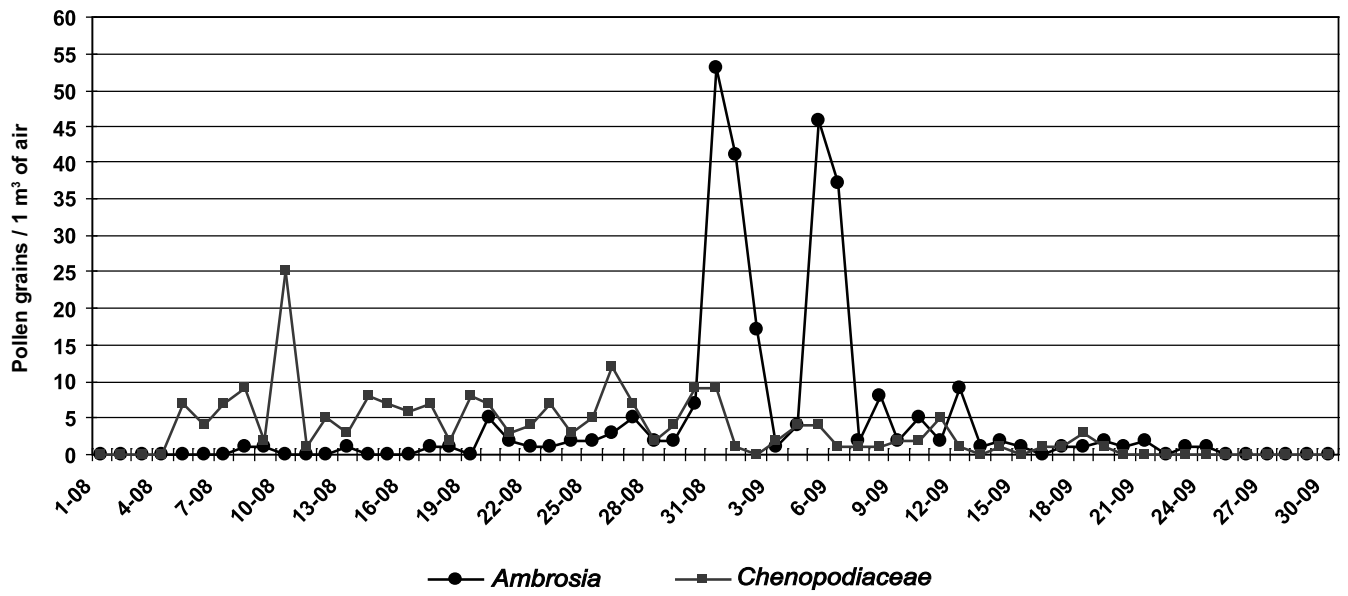

Fig.1. Daily variations in the atmospheric pollen of Ambrosia-type and Chenopodiaceae-type in August and September 
Polish one. This level might be qualified as high. The pollen forecast is usually presented as low, moderate, high or very high. According to customary scheme:

- low level is less than 30 pollen grains per cubic meter of air;

- moderate is from 30 to 49 pollen grains per cubic meter of air;

- high is from 50 to 149 pollen grains per cubic meter of air;

- very high is 150 or more pollen grains per cubic meter of air.

From the allergological point of view, there are several points of view about the number of ragweed pollen capable of causing the allergy. Symptomatological threshold value depends on individual symptoms and begins with an average daily concentration between 10 and 100 pollen grains in $\mathrm{m}^{3}$ of air for the most sensitive people $[2,55]$. In some other regions, e. g. in Austria, it seems to be a concentration of less than $20 \mathrm{p.g} . / \mathrm{m}^{3}$ of the outdoor air [26, 27]. Moreover, Dechamp et al. [13] fixed clinical threshold for allergic symptoms at a mean weekly concentration equal to or higher than $5 \mathrm{p.g.} / \mathrm{m}^{3}$.

Daily pollen concentrations exceeding $30 \mathrm{p.g} . / \mathrm{m}^{3}$ of air are generally accepted as the allergologic threshold value. Numbers of days with ragweed pollen concentration higher than 30 pollen grains per $\mathrm{m}^{3}$ of air were 2 in Wielkapolska region and 4 in Lviv city.

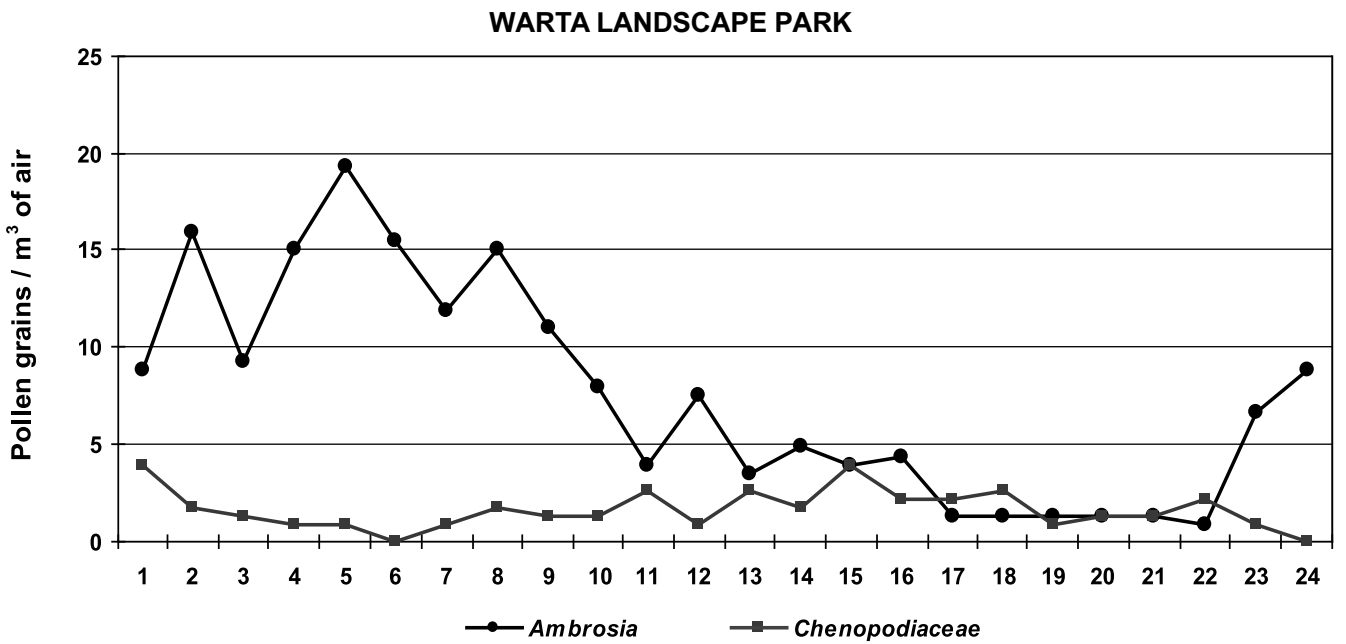

Fig.2. Average diurnal pollen periodicity

WARTA LANDSCAPE PARK

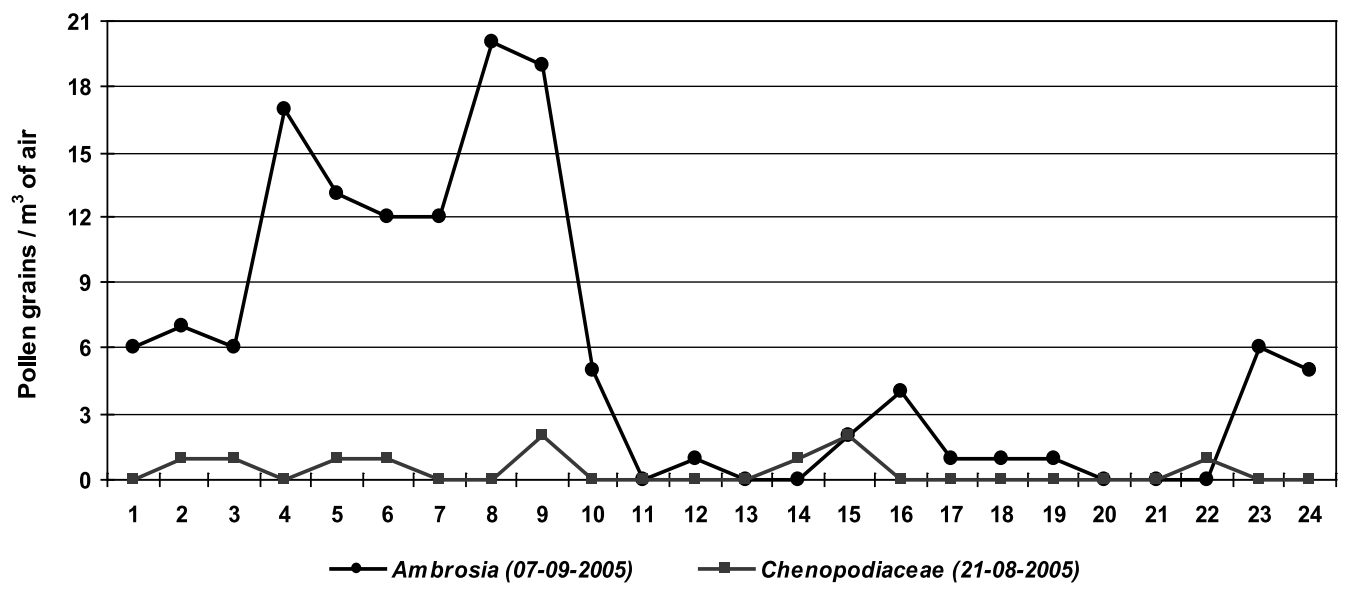

Fig.3. Diurnal pollen periodicity in day of pollination peak 

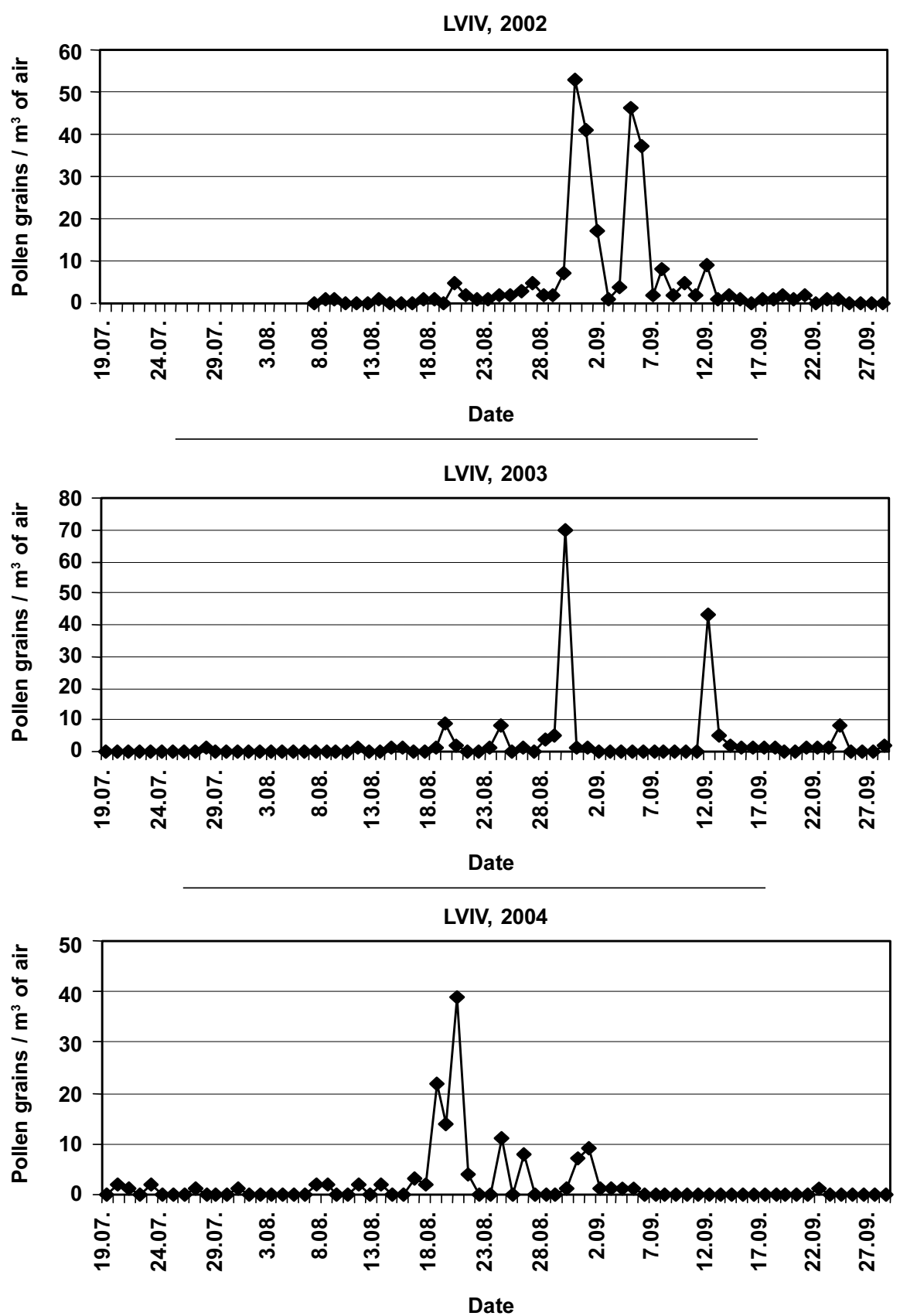

Fig.4. Daily variation in atmospheric pollen of Ambrosia-type in Lviv city in different years

In Wielkapolska, the average intradiurnal Ambrosia concentration peak ranged between 24.00 and 8.00 whereas in the day of the pollination maximum it ranged between 4.00 and 9.00 a.m. (Fig. 2, 3).

In different years, the duration and average daily Ambrosia pollen count in Lviv city have similar pattern of fluctuations (Fig. 4). The differences were found in time of appearance and in dates of maximum daily concentration recorded in 2002, 2003, and 2004. Several pollination peaks with two noticeably higher ones demonstrate 
similar patterns in different years. However, there is a tendency to earlier occurrence of Ambrosia pollination maximum.

In Wielkapolska, the Ambrosia and Chenopodiaceae pollen levels were equal during the whole sampling period except the pollination peaks when the maximum of Ambrosia daily concentration was six times higher than for Chenopodiaceae. In Lviv atmosphere, Chenopodiaceae pollen was more abundant, than Ambrosia pollen though in the pollination peaks ragweed daily concentration was four times higher than the that of pigweed.

\section{DISCUSSION}

Ambrosia pollen fall in Lviv city and in Wielkapolska region has similar pattern. Differences were found in time of the accurrence of pollination peaks. The similarity in ragweed pollen seasons in central Poland and western Ukraine can be explained by similar climatic and biogeographic conditions. The variations in ragweed airborne pollen concentrations greatly depend on weather conditions [1, 62]. Many investigations have shown that warm and dry periods during the formation of anthers could notably increase pollen in the atmosphere [20,41, 64]. The territory of western Ukraine is under the influence of Atlantic climate diffusion. It is characterized by natural forest vegetation. The central and eastern parts of Ukraine belong to the zone of continental climate with natural steppe-forest and steppe vegetation.

The ragweed population is well established in the eastern, southern and central regions of Ukraine, and covers the bare soils of wastelands or building locations, roadsides and fields with cultivated plants. Because of proper soil and weather conditions, Ambrosia individuals frequently reach 1.5-2 meters of height.

Wielkapolska region is located in the area of western circulation. However, the region is open to continental climatic influences. Artemisia populations are absent in Poznan vicinity. So the presence of its pollen in aeroplankton most probably is caused by distant transportation from Ukraine, the Czech Republic, Slovakia and Hungary. Transportation of ragweed pollen by air masses from distant sources has already been discussed. It was reported for Poznan that maximum of ragweed pollen was observed when eastern and southern winds blew [63]. In the Baltic states, it was found that incursions of ragweed pollen were determined by air fluxes originating from Ukraine, as well as from the southeastern and southern regions of the European part of Russia [54].

In Poznan and its vicinity, the Ambrosia pollen appears in aeroplankton at the end or in the middle of August. For comparison, in Vienna the pollination period lasts from the mid August to the end of September [28]. In Lviv city, we usually observed it earlier: from the middle of July. The same trend can be seen in the date of pollination peak: 7th of September (2005) in Wielkapolska region, and 31st of August (2002) in Lviv. Of course, the presented data about pollen fall in Warta Lanscape Park and Lviv in different years are not appropriate for accurate comparison. But there is a clear tendency to earlier accurrence of Ambrosia pollination maximum in Lviv in the range of consecutive years (2002-2004) (Fig. 4). It is suggested that in 2005 the difference in pollination peak dates in the investigated regions might be more than 7 days. For comparison, in Vienna the pollination peak appears usually at the beginning of September [28]. It can be explained by air transportation of ragweed pollen from the eastern regions of Europe to its western regions.

In general, the maximum concentrations of Ambrosia pollen grains in the regions with Ambrosia populations are recorded in the hours close to midday, when the meteorological conditions of temperature and humidity are more favourable for a release of pollen grains from the anthers and their dispersion by wind. Our observation in Wielkapolska region, revealed that the maximum emission of Ambrosia pollen into the 
atmosphere takes place at 5.00-8.00 a.m. Because of absence of Ambrosia population, this emission may be caused only by the distant transportation from the regions where the pollen grains were released before.

Our results show that critical period with daily Ambrosia pollen counts over the allergologic threshold value in Lviv and Wielkapolska region is very short and continues a few days. This is also typical for other regions of Poland [65]. Whereas in southward situated Croatia it continues for 19-54 days [48].

In the view of low number of days in the pollen season when the threshold values are exceeded, the ragweed pollinosis does not seem to be a major threat to allergic population in central regions of Poland and western part of Ukraine. However, the increase in carbon dioxide concentration and temperature rise may provoke increasing of Ambrosia pollen quantity and pollination season lengthening, that has already been reported for different European countries [7, 30, 37, 49].

\section{CONCLUSION}

In the aeroplankton of both regions under investigation higher concentration of Ambrosia pollen comparing to Chenopodiaceae pollen was recorded, despite pigweed population was significantly more abundant in territory of Poland and western Ukraine.

Chenopodiaceae pollen concentration counts 25 pollen grains per cubic meter of the air in Lviv and 15 pollen grains per cubic meter of the air in Wielkapolska region.

In the peaks of pollination, the Ambrosia pollen concentration reaches 50-60 pollen grains per cubic meter of air. From the allergological point of view, it may be qualified as high level.

Three peaks of Ambrosia pollination were revealed in Ukraine and Poland with a several days delay in Poland. This fact and previously obtained data that maximum of ragweed pollen in Wielkapolska region was noted when eastern and southern winds blew can explain the presence of Ambrosia pollen in aeroplankton by its distant transportation from Ukraine.

Aeropalynological monitoring in the eastern regions of Europe can provide the allergologic patients in the western parts of Europe with the preventive information.

The numbers of days with ragweed pollen concentration higher than 30 pollen grains per cubic meter of air (allergologic threshold value) were relatively low in both investigated regions. Nevertheless, the results of this study provide useful information to individuals with ragweed pollen allergy, allowing them to adjust their outdoor activity in order to avoid contacting with the allergen.

1. Adams-Groom B., Emberlin J., Corden J. e. a. Predicting the start of the birch pollen season at London, Derby and Cardiff, United Kingdom, using a multiple regression model, based on data from 1987 to 1997. Aerobiologia, 2002; 18: 117-123.

2. Banken R., Comtois $P$. Concentration of ragweed pollen and prevalence of allergic rhinitis in two municipalities in the Laurentides. Allergie et immunologie, 1992; 24: 91-94.

3. Bassett I.J., Crompton C.W., Parmelee J.A. An Atlas of Airborne Pollen Grains and Common Fumgus Spores of Canada. Ottawa, 1978. 322 p.

4. Bush $R$. Aerobiology of pollen and fungal allergens. Journal of investigational allergology \& clinical immunology (J. Allergy Clin. Immunol), 1989; 84: 1120-1124.

5. Chappard C., Bonnevial J., Colson M. e. a. Forecast of pollination dates and relation to onset of allergic pathology. Aerobiologia, 2004; 20: 35-42.

6. Ciancianaini P., Albertini R., Pinelli S. e. a. Parma (Northern Italy): Pollen calendars from 1995 to 1997. Aerobiologia, 2000; 16: 309-312. 
7. Clot B. Trends in airborne pollen: An overview of 21 years of data in Neuchâtel (Switzerland). Aerobiologia, 2003; 19: 227-234.

8. Corden J., Millington W., Bailey J. e a. UK regional variations in Betula pollen (1993-1997). Aerobiologia, 2000; 16: 227-232.

9. Czarnecka-Operacz M. Allergy and pollinosis. Postępy dermatologii i alergologii, 2003; XX (4): 230-234.

10. Czernećkyj M. Pyłek astrowatych (Asteraceae) w atmosferze Lwowa. Biologia kwitnienia roślin i alergie pyłkowe. Streszczenia. V Ogólnopolska Konferencja Naukowa. Lublin, 9-10 listopada 2005. Lublin, 2005: 92.

11. D'Amato G. European airborne pollen types of allergological interest and monthly appearance of pollination in Europe. In: G. D'Amato, F.Th.M. Spieksma and S. Bonini (Ed.) Allergenic Pollen and Pollinosis in Europe. Oxford: Blackwell, 1991: 66-78.

12. D'Amato G., Errigo E., Bonini S. Allergenic pollen and pollinosis in Italy. In: G. D'Amato, F.Th.M. Spieksma and S. Bonini (Ed.) Allergenic Pollen and Pollinosis in Europe. Oxford: Blackwell, 1991: 176-181.

13. Dechamp C., Rimet M.L., Meon H., Deviller P. Parameters of ragweed pollination in the Lyon's area (France) from 14 years of pollen counts. Aerobiologia, 1997; 13: 275-279.

14. Emberlin J. Aerobiology, aerodynamics and pollen sampling. Postępy dermatologii i alergologii, 2003; XX (4): 196-199.

15. Emberlin J. Meteorological aspects of particle dispersal. Postępy dermatologii i alergologii, 2003; XX (4): 209-211.

16. Emberlin J., Jaeger S., Dominguez-Vilches E. e. a. Temporal and geographical variations in grass pollen seasons in areas of western Europe: an analysis of season dates at sites of the European pollen information system. Aerobiologia, 2000; 16: 373-379.

17. Frenguelli $G$. Basic microscopy, calculating the field of view, scanning of slides, sources of error. Postępy dermatologii i alergologii, 2003; XX (4): 227-229.

18. Frostad A. Allergenic pollen and pollinosis in Norwey. In: G. D'Amato, F.Th.M. Spieksma and S. Bonini (Ed.) Allergenic Pollen and Pollinosis in Europe. Oxford: Blackwell, 1991: 182-183.

19. Galan C. Quality control in aerobiological networks. Postępy dermatologii i alergologii, 2003; XX (4): 244-245.

20. Galán C., Emberlin J., Dominiquez E. e. a. A comparative analysis of daily variations in the Gramineae pollen counts in Cordoba, Spain and London, UK. Grana, 1995; 34: 189-198.

21. Gehrig R. The influence of the hot and dry summer 2003 on the pollen season in Switzerland. Aerobiologia, 2006; 22, 1: 27-34.

22. Güvensen A., Öztürk M. Airborne pollen calendar of Buca-Izmir, Turkey. Aerobiologia, 2002; 18: 229-237.

23. Hansen A. Ambrosia L. In: Tutin T.G. et al. (Ed.). Flora Europaea, Vol. 4. Cambridge: Cambridge Univ. Press, 1976: 142-143.

24. Hirst J.M. An automatic volumetric spore trap. Annals of Applied Biology, 1952; 39: 257-65.

25. Hofman T., Stach A. Pollen fall and pollinosis morbidity in Poznan during 1993-1994. In: Pollens and Pollinosis: Current Problems. Lublin: Institute of Agricultural Medicine, 1995: 43-46.

26. Jäger S. Allergenic significance of Ambrosia (Ragweed). In: G. D'Amato, F.Th.M. Spieksma and S. Bonini (Ed.) Allergenic Pollen and Pollinosis in Europe. Oxford: Blackwell, 1991: 125-127.

27. Jäger S. Global aspect of ragweed in Europe. In: $\mathbf{6}^{\text {th }}$ Int. Cong. on Aerobiology, Satellite Symposium Proceedings: Ragweed in Europe. Perugia, 31 August5 September 1998. Perugia, 1998: 6-11.

28. Jäger S. Ragweed (Ambrosia) Sensitisation Rates Correlate with the Amount of Inhaled Airborne Pollen. A 14-year Study. Aerobiologia, 2000; 16: 149-153. 
29. Jäger $S$. The European Pollen Information System (epi). Data bank (EAN), Web sites and forecasting. Postępy dermatologii i alergologii, 2003; XX (4): 239-243.

30. Jäger S., Litschauer R. Ragweed (Ambrosia) in Austria. In: $6^{\text {th }}$ Int. Cong. on Aerobiology, Satellite Symposium Proceedings: Ragweed in Europe. Perugia, 31 August-5 September 1998. Perugia, 1998: 22-27.

31. Johnson C., Rasmussen A., Weeke E. Allergenic pollen and pollinosis in Denmark. In: G. D'Amato, F.Th.M. Spieksma and S. Bonini (Ed.) Allergenic Pollen and Pollinosis in Europe. Oxford: Blackwell, 1991: 151-158.

32. Kadocsa E., Juhász $M$. Study of airborne pollen composition and allergen spectrum of hay fever patients in South Hungary (1990-1999). Aerobiologia, 2002; 18: 203-209.

33. Kalinovych N., Pavlyk Ju. Chenopodiaceae-type pollen content in the atmosphere of Lviv city. Proceeding of International Conference „Plant ontogenesis in natural and man made habitats: physiological, biochemical and ecological aspects", Lviv, 18-24 August 2004. Lviv, 2004: 343.

34. Kalinovych N., Pavlyshyn S. Airborne pollen in Lviv. Proceeding of Second European Symposium on Aerobiology, Vienna, 5-9 September 2000. Vienna, 2000: 84.

35. Kaya Z., Aras A. Airborne pollen calendar of Bartin, Turkey. Aerobiologia, 2004; 20: 63-67.

36. Kersten W., Von Wahl P.-G., Debelic M. Allergenic pollen and pollinosis in Western Germany. In: G. D'Amato, F.Th.M. Spieksma and S. Bonini (Ed.). Allergenic Pollen and Pollinosis in Europe. Oxford: Blackwell, 1991: 164-166.

37. Laaidi K., Laaidi M. Airborne pollen of Ambrosia in Burgundy (France) 1996-1997. Aerobiologia, 1999; 15: 65-69.

38. Leuschner R.M., Christen H., Jordan P., Vonthein R. 30 years of studies of grass pollen in Basel (Switzerland). Aerobiologia, 2000; 16: 381-391.

39. Maggi O., Persiani A.M., Gallo F. e. a. Airborne fungal spores in dust present in archives: proposal for a detection methods, new for archival materials. Aerobiologia, 2000; 16: 429-434.

40. Majd A., Chehregani A., Moin M. e.a. The effects of air pollution on structures, proteins and allergenicity of pollen grains. Aerobiologia, 2004; 20: 111-118.

41. Makra L., Juhasz M., Borsos E., Beczi R. Meteorological variables connected with airborne ragweed pollen in Southern Hungary. Int. J. Biometeorol, 2004; 49: 37-47.

42. Montaculelli R., Maggi O., Tarsitani G., Gabrielli N. Aerobiological monitoring of the „Sistine Chapel": airborne bacteria and microfungi trends. Aerobiologia, 2000; 16: 441-448.

43. Monte M., Ferrari R. Airborne microorganisms in a subterranean archaeological area of the basilica of San Lorenzo in Lucina (Rome). Aerobiologia, 2000; 16: 435-439.

44. Myszkowska D., Stępalska D., Obtułowicz K., Porębski G. The relationship between airborne pollen and fungal spore concentrations and seasonal pollen allergy symptoms in Cracow in 1997-1999. Aerobiologia, 2002; 18: 153-161.

45. Nugari M.P. The aerobiology applied to the conservation of works of art. Coalition, 2003; 6 (2): 8-10.

46. Nugari M.P., Roccardi A. Aerobiological investigations applied to the conservation of cultural heritage. Aerobiologia, 2001; 17: 215-223.

47. Osvath P. Allergenic pollen and pollinosis in Hungary. In: G. D'Amato, F.Th.M. Spieksma and S. Bonini (Ed.). Allergenic Pollen and Pollinosis in Europe. Oxford: Blackwell, 1991: 172-175.

48. Peterne R., Čulig J., Srnec L. e. a. Variation in ragweed (Ambrosia artemisiifolia L.) pollen concentration in Central Croatia, 2002-2003. Ann. Agric. Environ. Med, 2005; 12: 11-16.

49. Puc M. Ragweeed pollen in the air of Szczecin. Ann. Agric. Environ. Med, 2004; 11: 53-57.

50. Rantio-Lehtimäki A., Matikainen E. Pollen allergen reports help to understand preseason symptoms. Aerobiologia, 2002; 18: 135-140. 
51. Riediker M., Koller T., Monn C. Determination of birch pollen allergens in different aerosol sizes. Aerobiologia, 2000; 16: 251-254.

52. Riera M., Cerda T., Martín J. A correlation study between airborne pollen and cases of pollinosis in humans. Aerobiologia, 2002; 18: 169-173.

53. Ross A.M., Fleming D.M. Incidence of allergic rhinitis in general practice, 1981-92. British Medical Journal, 1994; 308: 897-900.

54. Saar M., Gudžinskas Z., Ploompuu T. e. a. Ragweed Plans and Airborne Pollen in the Baltic States. Aerobiologia, 2000; 16: 101-106.

55. Solomon W.R. Aerobiology of pollinosis. J. Allergy Clin. Immunol, 1984; 74: 449-461.

56. Spieksma F. Allergenic pollen and pollinosis in the Netherlands. In: G. D'Amato, F.Th.M. Spieksma and S. Bonini (Ed.). Allergenic Pollen and Pollinosis in Europe. Oxford: Blackwell, 1991: 203-206.

57. Spieksma F. Regional European pollen calendars. In: G. D’Amato, F.Th.M. Spieksma and S. Bonini (Ed.). Allergenic Pollen and Pollinosis in Europe. Oxford: Blackwell, 1991: 49-65.

58. Spieksma F. The history of European Course on Basic Aerobiology (ECBA). Postępy dermatologii i alergologii, 2003; XX (4): 192-195.

59. Spieksma F., Corden J., Detandt M. e. a. Quantitative trends in annual totals of five common airborne pollen types (Betula, Quercus, Poaceae, Urtica, and Artemisia), at five pollen-monitoring stations in western Europe. Aerobiologia, 2003; 19: 171-184.

60. Stach A. Pollen fall of certain allergenic plants in Poznan in the years 1992-1995. The basis for the compilation of a pollen calendar for Poznan and surrounding area. In: Pollens and Pollinosis: Current Problems. Lublin: Institute of Agricultural Medicine, 1995: 27-28.

61. Stach $A$. The use of Hirst volumetric trap, preparation of drums and slides. Postępy dermatologii i alergologii, 2003; XX (4): 246-249.

62. Stach $A$. Variation in pollen concentration of the most allergenic taxa in Poznań (Poland), 1995-1996. Aerobiologia, 2000; 16: 63-68.

63. Stach A., Silny W. Pyłek z dalekiego transportu w aeroplanktonie Poznania w latach 1995-1997 (wybrane taxony alergogenne). Bibliotheca Fragmenta Agronomica, 1999; 99, (6): 109-116.

64. Stefanic E., Kovacevic V., Lazanin Z. Airborne Ragweed Pollen Concentration in North-Eastern Croatia and its Relationship with Meteorological Parameters. Ann. Agric. Environ. Med, 2005; 12: 75-79.

65. Stepalska D., Szczepanek K., Myszkowska D. Variation in Ambrosia pollen concentration in Southern and Central Poland in 1982-1999. Aerobiologia, 2002; 18, 13-22.

66. Szczepanek K. Pollen fall in Krakow in 1982-1991. Zesz. Nauk. Uniw. Jagiell. Prace Geogr, 1994; 97: 9-22.

67. Weerd N., Bhalla P., Singh M. Aeroallergens and pollinosis: Molecular and immunological characteristics of cloned pollen allergens. Aerobiologia, 2002; 18: 87-106.

68. Weryszko-Chmielewska E. Pollen development, biology and function. Postępy dermatologii i alergologii, 2003; XX (4): 212-217.

69. Weryszko-Chmielewska E., Piotrowska K., Czernećkyj M. Pyłek ambrozji (Ambrosia) i iwy (Iva) w powietrzu Lublina i Lwowa. Annales Universitatis Mariae Curie-Skłodowska. Sec. Horticultura, 2003; XIII: 341-348.

70. Woś $A$. The Climate of the Wielkopolska Lowland. Poznań, 1994. $192 \mathrm{p}$.

71. Zając A., Zając M. (Ed.). Distribution Atlas of Vascular Plants in Poland. Cracow, 2001. $717 \mathrm{p}$. 